\title{
Tris(ethylenediamine) cobalt(II) and manganese(II) nitrates: synthesis, structure and crystal handedness mapping by $\mathrm{X}$-ray circular dichroism
}

${ }^{1}$ CNRS, Univ Bordeaux, Centre de Recherche Paul Pascal, UMR 5031, Pessac, France. ${ }^{2}$ CNRS, Univ. Bordeaux, Bordeaux INP, ICMCB, UMR 5026, Pessac, France. ${ }^{3}$ European Synchrotron Radiation Facility, Grenoble, France. ${ }^{4}$ Institut de Minéralogie, de Physique des Matériaux et de Cosmochimie, Paris, France. 
Abstract: Enantiomers of $\left[\mathrm{Ni}(\mathrm{en})_{3}\right]\left(\mathrm{NO}_{3}\right)_{2}$ and $\left[\mathrm{Zn}(\mathrm{en})_{3}\right]\left(\mathrm{NO}_{3}\right)_{2}(\mathrm{en}=$ ethylenediamine) spontaneously resolve to form a conglomerate, and present a reversible phase transition from space group $P 6_{3} 22$ to $P 6_{5} 22$ or $P 6_{1} 22$. To extend the family of such compounds, we have investigated the isostructural $\left[\mathrm{Mn}(\mathrm{en})_{3}\right]\left(\mathrm{NO}_{3}\right)_{2}$ and $\left[\mathrm{Co}(\mathrm{en})_{3}\right]\left(\mathrm{NO}_{3}\right)_{2}$. The $\mathrm{Mn}(\mathrm{II})$ analogue undergoes the same phase transition at $150(2) \mathrm{K}$, while the $\mathrm{Co}(\mathrm{II})$ derivative does not demonstrate a phase transition down to $2 \mathrm{~K} .{ }^{1}$

Although conglomerate formation allows non-centrosymmetric crystals to be effortlessly obtained, spontaneous resolution is only accomplished after the identification crystal handedness. We have implemented an original method for determining the handedness of individual crystals in a mixture using a tightly-focused, circularly polarized X-ray beam. ${ }^{2}$ The $\mathrm{X}$-ray natural circular dichroism spectra measured at the metal K-edge on crystals of $\left[\mathrm{Co}(\mathrm{en})_{3}\right]\left(\mathrm{NO}_{3}\right)_{2}$ and $\left[\mathrm{Ni}(\mathrm{en})_{3}\right]\left(\mathrm{NO}_{3}\right)_{2}$ show maxima at the metal pre-edge. A mapping of a collection of crystals was performed at this energy; the sign of the difference in absorption for the two polarizations directly yields the handedness of the crystal.

1) M. Cortijo, A. Valentin-Perez, M. Rouzières, R. Clérac, P. Rosa, E.A. Hillard, Crystals, 2020, 10(6), 472 https://doi.org/10.3390/cryst10060472.

2) M. Cortijo, A. Valentin-Perez, A. Rogalev, F. Wilhelm, Ph. Sainctavit, P. Rosa, E.A. Hillard, Chem. Eur. J., 2020, https://doi.org/10.1002/chem.202001783 


\section{Introduction}

Chirality in octahedral coordination compounds

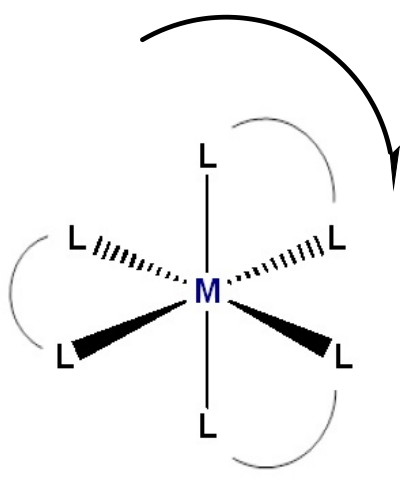

$\Delta$

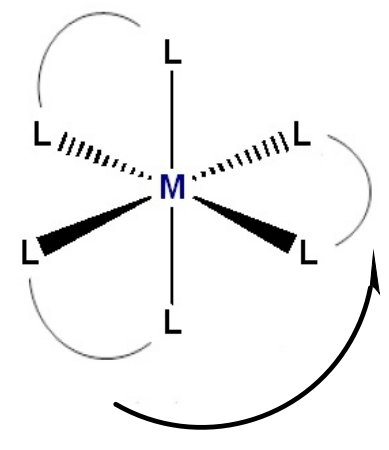

$\Lambda$

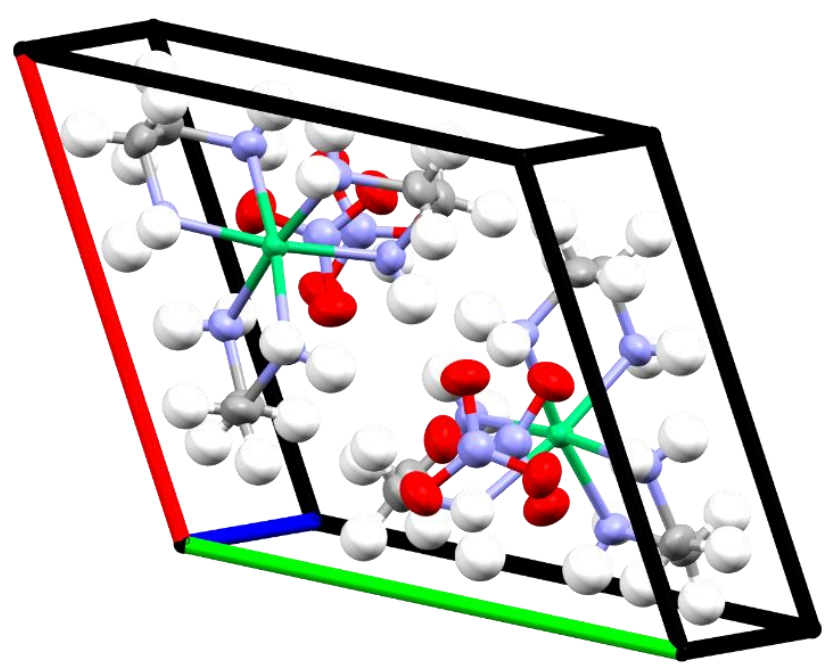

Octahedral tris(bidentate) coordination complexes demonstrate helicoidal chirality due to the clockwise or counterclockwise arrangement of the ligands around the metal core.

An example is $\left[\mathrm{Ni}(\mathrm{en})_{3}\right]\left(\mathrm{NO}_{3}\right)_{2}(\mathrm{en}=$ ethylenediamine) which crystallizes in the space group $\mathrm{P}_{3} 22$ at room temperature.

L. J. Farrugia et al. J. Appl. Cryst. 2003, 36, 141. 


\section{Introduction}

\section{$\left[\mathrm{M}(\mathrm{en})_{3}\right]\left(\mathrm{NO}_{3}\right)_{2}$ : Noncentrosymmetric crystals}

As part of our interest in X-ray natural circular dichroism (XNCD), we wished to extend this series of $\left[\mathrm{M}(\mathrm{en})_{3}\right]\left(\mathrm{NO}_{3}\right)_{2}$ compounds to obtain non-centrosymmetrc crystals of optical quality and high crystal symmetry.

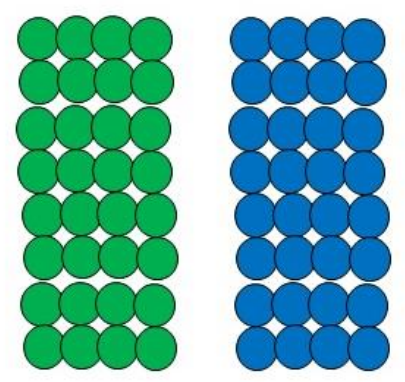

Conglomerate

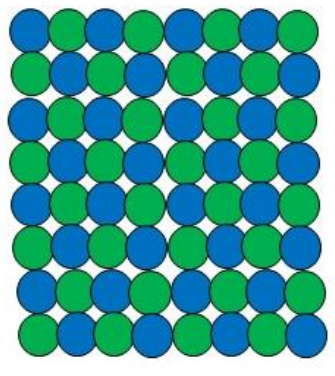

Racemic compound
The known $\mathrm{Ni}(\mathrm{II})$ and $\mathrm{Zn}(\mathrm{II})$ complexes undergo spontaneous resolution by conglomerate formation, such that the enantiomers segregate into noncentrosymmetric crystals.

Attempts were made to synthesize complexes of the late transition metals, and the new Mn(II) and $\mathrm{Co}$ (II) analogues were obtained.

P. V. Bernhardt et al. Aust. J. Chem. 2003, 56, 287.

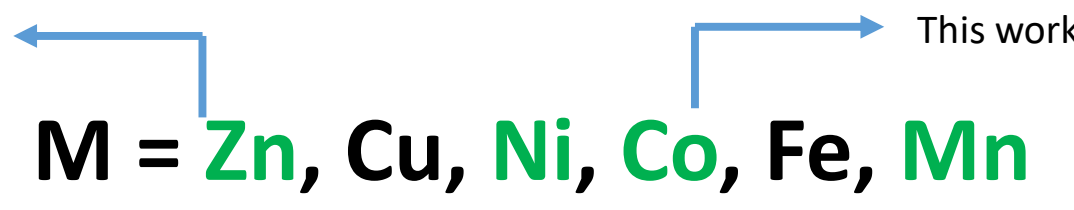
Jahn-Teller distortion forming achiral $\mathrm{Cu}(\mathrm{en})_{2}\left(\mathrm{NO}_{3}\right)_{2}$ 


\section{Results and discussion}

\section{Manganese(II) and cobalt(II) derivatives}

$\left[\mathrm{Mn}(\mathrm{en})_{3}\right]\left(\mathrm{NO}_{3}\right)_{2}$ and $\left[\mathrm{Co}(\mathrm{en})_{3}\right]\left(\mathrm{NO}_{3}\right)_{2}$ were found to be isostructural to the $\mathrm{Zn}(\mathrm{II})$ and $\mathrm{Ni}(\mathrm{II})$ derivatives, crystallizing as conglomerates in $\mathrm{P}_{3} 22$ at room temperature.

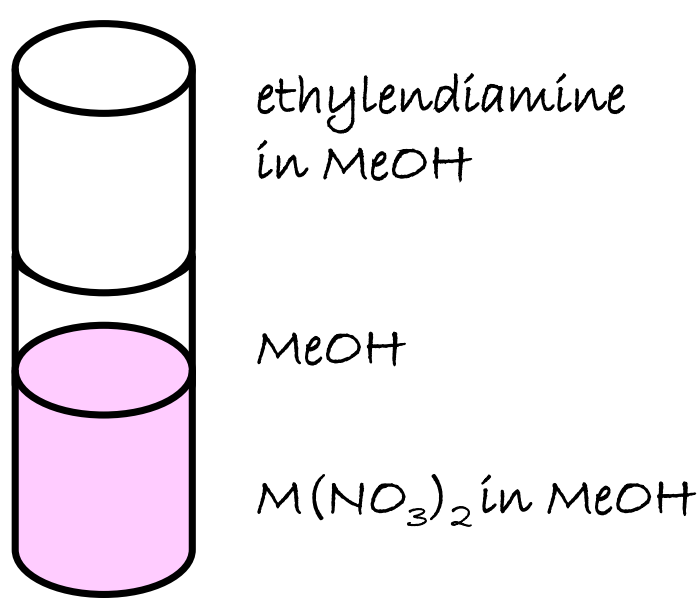

Crystallization of $\left[\mathrm{Mn}(\mathrm{en})_{3}\right]\left(\mathrm{NO}_{3}\right)_{2}$ and $\left[\mathrm{Co}(\mathrm{en})_{3}\right]\left(\mathrm{NO}_{3}\right)_{2}$ via slow diffusion of methanolic solutions in inert atmosphere. L-ascorbic acid was added as an antioxidant to the $\mathrm{Co}(\mathrm{II})$ reaction.

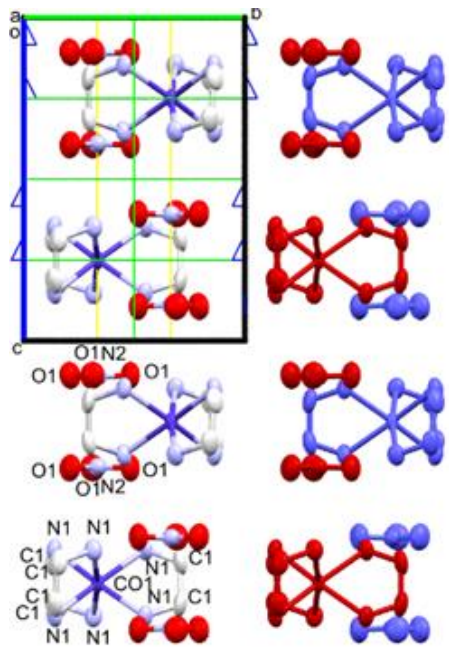

(a)

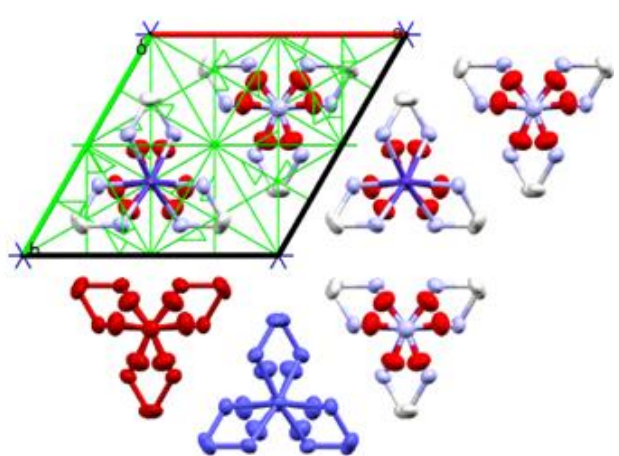

(b)

Anisotropic displacement ellipsoid plot (Mercury, 50\% probability) of $\Delta$-[Co(en $\left.)_{3}\right]\left(\mathrm{NO}_{3}\right)_{2}$ at $298 \mathrm{~K}$ as viewed down the (a) $a$ and (b) $c$ crystal axes. Space group $P 6_{3} 22$. Unit cell and symmetry axes are shown, with blue $=6$-fold screw, yellow $=3$ -

fold and green $=2$-fold axes. Different columns are indicated by red and blue molecules. $\mathrm{H}$ atoms omitted for clarity. 


\section{Results and discussion}

\section{Crystallographic data for $\left[\mathrm{M}(\mathrm{en})_{3}\right]\left(\mathrm{NO}_{3}\right)_{2}$ at $298 \mathrm{~K}$}

\begin{tabular}{|c|c|c|c|c|}
\hline & $\Delta-\mathrm{Mn}$ & $\Lambda-M n$ & $\Delta$-Co & $\Lambda$-Сo \\
\hline Formula & $\mathrm{C}_{6} \mathrm{H}_{24} \mathrm{MnN}_{8} \mathrm{O}_{6}$ & $\mathrm{C}_{6} \mathrm{H}_{24} \mathrm{MnN}_{8} \mathrm{O}_{6}$ & $\mathrm{C}_{6} \mathrm{H}_{24} \mathrm{CoN}_{8} \mathrm{O}_{6}$ & $\mathrm{C}_{6} \mathrm{H}_{24} \mathrm{CoN}_{8} \mathrm{O}_{6}$ \\
\hline Formula weight & 359.25 & 359.25 & 363.26 & 363.26 \\
\hline Crystal system & \multicolumn{4}{|c|}{ hexagonal } \\
\hline Space group & \multicolumn{4}{|c|}{$\mathrm{P}_{3} 22$ (no. 182) } \\
\hline$a, b$ & $9.057(3) \AA$ & $9.0572(7) \AA ̊$ & $8.9285(8) \AA ̊$ & $8.9158(8) \AA$ \\
\hline c & $11.301(3) \AA$ & $11.3115(10) \AA ̊$ & $11.3126(11) \AA$ & $11.2970(10) \AA ̊$ \\
\hline$\alpha, \beta$ & \multicolumn{4}{|c|}{$90^{\circ}$} \\
\hline$\gamma$ & \multicolumn{4}{|c|}{$120^{\circ}$} \\
\hline Volume & $802.8(4) \AA^{3}$ & $803.60(11) \AA^{3}$ & $781.00(16) \AA^{3}$ & $777.70(16) \AA^{3}$ \\
\hline$Z$ & \multicolumn{4}{|c|}{2} \\
\hline$\rho_{\text {calc }}$ & $1.4861 \mathrm{~g} / \mathrm{cm}^{3}$ & $1.4846 \mathrm{~g} / \mathrm{cm}^{3}$ & $1.545 \mathrm{~g} / \mathrm{cm}^{3}$ & $1.551 \mathrm{~g} / \mathrm{cm}^{3}$ \\
\hline$\mu($ Mo K $\alpha)$ & $0.861 \mathrm{~mm}^{-1}$ & $0.860 \mathrm{~mm}^{-1}$ & $1.138 \mathrm{~mm}^{-1}$ & $1.143 \mathrm{~mm}^{-1}$ \\
\hline $\begin{array}{l}\text { Reflections } \\
\text { collected }\end{array}$ & $\begin{array}{c}21940 \\
\left(5.2^{\circ} \leq 2 \theta \leq 56.6^{\circ}\right)\end{array}$ & $\begin{array}{c}9221 \\
\left(5.2^{\circ} \leq 2 \theta \leq 52.8^{\circ}\right)\end{array}$ & $\begin{array}{c}6378 \\
\left(5.3^{\circ} \leq 2 \theta \leq 52.7^{\circ}\right)\end{array}$ & $\begin{array}{c}20782 \\
\left(6.4^{\circ} \leq 2 \theta \leq 52.9^{\circ}\right)\end{array}$ \\
\hline Unique & $675\left[R_{\mathrm{int}}=0.0356\right]$ & $560\left[R_{\mathrm{int}}=0.0301\right]$ & $545\left[R_{\mathrm{int}}=0.0216\right]$ & $542\left[R_{\mathrm{int}}=0.0213\right]$ \\
\hline $\begin{array}{l}\text { Final } R \text { indexes } \\
\text { [all data] }\end{array}$ & $\begin{array}{c}R_{1}=0.0279 \\
w R_{2}=0.0742\end{array}$ & $\begin{array}{c}R_{1}=0.0343 \\
w R_{2}=0.0894\end{array}$ & $\begin{array}{c}R_{1}=0.0232 \\
\mathrm{w} R_{2}=0.0766\end{array}$ & $\begin{array}{c}R_{1}=0.0176 \\
w R_{2}=0.0462\end{array}$ \\
\hline Flack para. & $0.07(5)$ & $0.04(7)$ & $-0.007(8)$ & $0.02(5)$ \\
\hline
\end{tabular}

M. Cortijo, A. Valentin-Perez, M. Rouzières, R. Clérac, P. Rosa, E.A.

Hillard, Crystals, 2020, 10(6), 472 https://doi.org/10.3390/cryst10060472. 


\section{Results and discussion}

Low temperature phase of $\left[\mathrm{Mn}(\mathrm{en})_{3}\right]\left(\mathrm{NO}_{3}\right)_{2}$

$\left[\mathrm{Mn}(\mathrm{en})_{3}\right]\left(\mathrm{NO}_{3}\right)_{2}$ undergoes a phase transition between 298 and $120 \mathrm{~K}$ involving a tripling of the $c$ axis and the generation of helicity in the columns (similar to the $\mathrm{Zn}$ (II) and $\mathrm{Ni}(\mathrm{II})$ analogues).

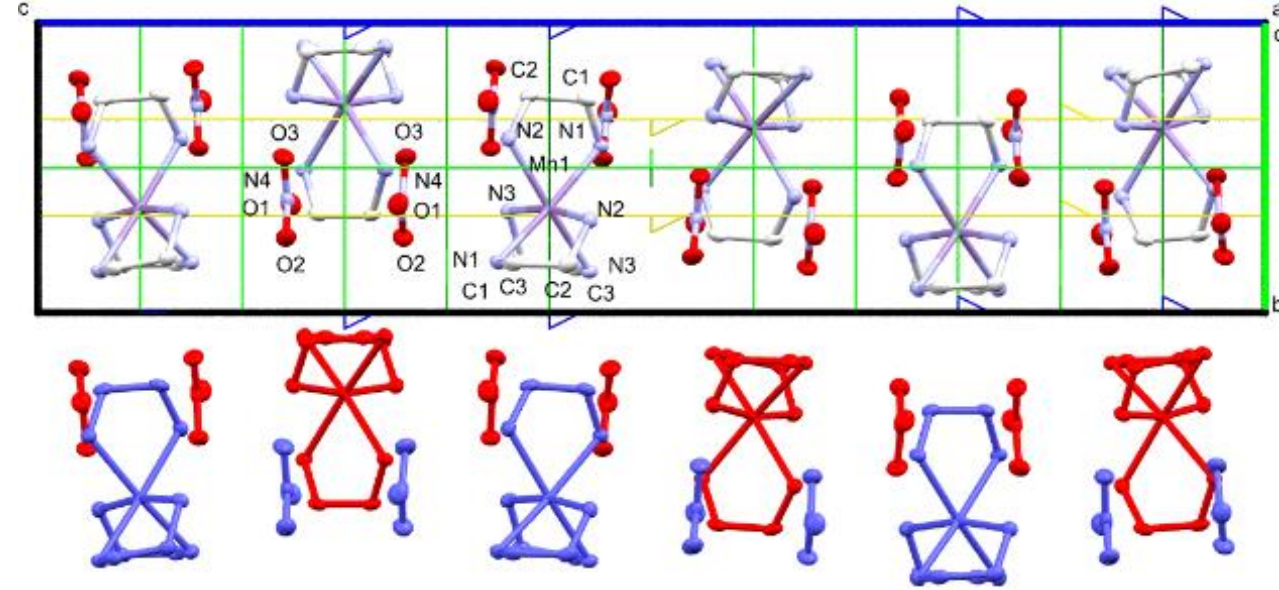

(a)

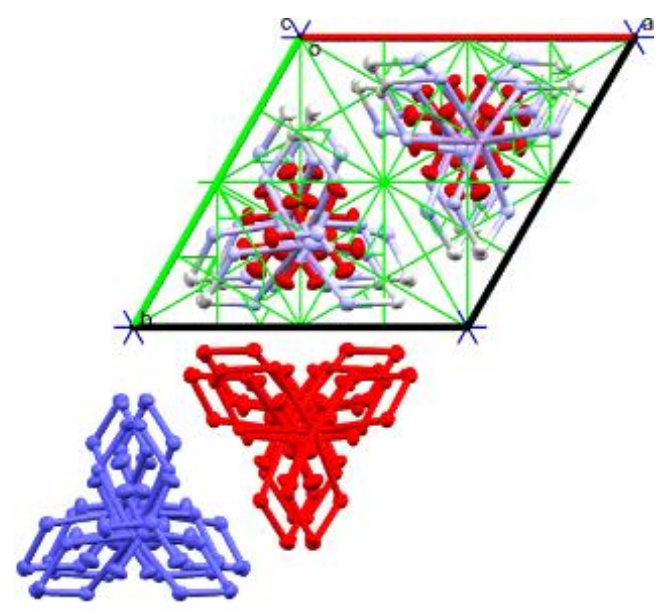

(b)

Anisotropic displacment ellipsoid plot (Mercury, $50 \%$ probability) of $\Lambda$-[Mn(en $\left.)_{3}\right]\left(\mathrm{NO}_{3}\right)_{2}$ at $120 \mathrm{~K}$ as viewed down the (left) $a$ crystal axis and (right) $c$ crystal axis. Unit cell and symmetry axes are shown, with blue $=6$-fold screw, yellow $=3$-fold and green $=2$-fold. Hydrogen atoms have been omitted for clarity.

No phase transition was detected in $\left[\mathrm{Co}(\mathrm{en})_{3}\right]\left(\mathrm{NO}_{3}\right)_{2}$ at $120 \mathrm{~K}$. 


\section{Results and discussion}

\section{Crystallographic data for $\left[\mathrm{M}(\mathrm{en})_{3}\right]\left(\mathrm{NO}_{3}\right)_{2}$ at $120 \mathrm{~K}$}

\begin{tabular}{|c|c|c|c|c|}
\hline & $\Delta-\mathrm{Mn}$ & $\Lambda-\mathrm{Mn}$ & $\Delta$-Co & $\Lambda$-Co \\
\hline Formula & $\mathrm{C}_{6} \mathrm{H}_{24} \mathrm{MnN}_{8} \mathrm{O}_{6}$ & $\mathrm{C}_{6} \mathrm{H}_{24} \mathrm{MnN}_{8} \mathrm{O}_{6}$ & $\mathrm{C}_{6} \mathrm{H}_{24} \mathrm{CoN}_{8} \mathrm{O}_{6}$ & $\mathrm{C}_{6} \mathrm{H}_{24} \mathrm{CoN}_{8} \mathrm{O}_{6}$ \\
\hline Formula weight & 359.25 & 359.25 & 363.24 & 363.26 \\
\hline Crystal system & \multicolumn{4}{|c|}{ hexagonal } \\
\hline Space group & $\mathrm{P}_{5} 22$ (no. 179) & P6 22 (no. 178) & $\mathrm{P}_{3} 22$ (no. 182) & $\mathrm{P}_{3} 22$ (no. 182) \\
\hline$a, b$ & $8.9999(3) \AA$ & $8.9970(3) \AA$ & $8.901(2) \AA$ & $8.8970(4) \AA$ \\
\hline c & $33.0883(14) \AA$ & $33.0623(11) \AA$ & $11.065(3) \AA$ & $11.0675(4) \AA$ \\
\hline$\alpha, \beta$ & \multicolumn{4}{|c|}{$90^{\circ}$} \\
\hline$v$ & \multicolumn{4}{|c|}{$120^{\circ}$} \\
\hline Volume & $2321.03(15) \AA^{3}$ & $2317.71(13) \AA^{3}$ & $759.2(3) \AA^{3}$ & $758.70(7) \AA^{3}$ \\
\hline$Z$ & 6 & 6 & 2 & 2 \\
\hline$\rho_{\text {calc }}$ & $1.5420 \mathrm{~g} / \mathrm{cm}^{3}$ & $1.5442 \mathrm{~g} / \mathrm{cm}^{3}$ & $1.5889 \mathrm{~g} / \mathrm{cm}^{3}$ & $1.590 \mathrm{~g} / \mathrm{cm}^{3}$ \\
\hline$\mu($ Mo K $\alpha)$ & $0.893 \mathrm{~mm}^{-1}$ & $0.894 \mathrm{~mm}^{-1}$ & $1.171 \mathrm{~mm}^{-1}$ & $1.172 \mathrm{~mm}^{-1}$ \\
\hline $\begin{array}{l}\text { Reflections } \\
\text { collected }\end{array}$ & $\begin{array}{c}19332 \\
\left(5.2^{\circ} \leq 2 \theta \leq 56.6^{\circ}\right)\end{array}$ & $\begin{array}{c}33347 \\
\left(5.2^{\circ} \leq 2 \theta \leq 50.7^{\circ}\right)\end{array}$ & $\begin{array}{c}5187 \\
\left(5.3^{\circ} \leq 2 \theta \leq 50.6^{\circ}\right)\end{array}$ & $\begin{array}{c}2055 \\
\left(5.3^{\circ} \leq 2 \theta \leq 52.7^{\circ}\right)\end{array}$ \\
\hline Unique & $1920\left[R_{\mathrm{int}}=0.0300\right]$ & $1419\left[R_{\text {int }}=0.0350\right]$ & $475\left[R_{\mathrm{int}}=0.0285\right]$ & $522\left[R_{\mathrm{int}}=0.0199\right]$ \\
\hline $\begin{array}{l}\text { Final } R \text { indexes } \\
\text { [all data] }\end{array}$ & $\begin{array}{c}R_{1}=0.0255 \\
w R_{2}=0.0656\end{array}$ & $\begin{array}{c}R_{1}=0.0203 \\
w R_{2}=0.0474\end{array}$ & $\begin{array}{c}R_{1}=0.0163 \\
w R_{2}=0.0444\end{array}$ & $\begin{array}{c}R_{1}=0.0186 \\
w R_{2}=0.0488\end{array}$ \\
\hline Flack para. & $0.04(3)$ & $0.01(3)$ & $0.01(5)$ & $0.006(8)$ \\
\hline $\begin{array}{l}\mathrm{a} \mathrm{R}_{1}=\Sigma|| \mathrm{F}_{\mathrm{o}}|-| \mathrm{F}_{\mathrm{c}} \\
\left.2\left(\mathrm{~F}_{\mathrm{c}}^{2}\right)\right] / 3 .\end{array}$ & $\mathrm{F}_{\mathrm{o}} \mid ; \mathrm{wR}_{2}=\left[\Sigma\left[\mathrm{w}\left(\mathrm{F}_{\mathrm{o}}^{2}\right.\right.\right.$ & ]$\left./ \Sigma\left[w\left(F_{o}^{2}\right)^{2}\right]\right]^{1 / 2}, w$ & $\left.:_{0}^{2}\right)+(a P)^{2}+b P$ & $P=\left[\max \left(0\right.\right.$ or $\left.F_{o}{ }^{2}\right)+$ \\
\hline
\end{tabular}

M. Cortijo, A. Valentin-Perez, M. Rouzières, R. Clérac, P. Rosa, E.A.

Hillard, Crystals, 2020, 10(6), 472 https://doi.org/10.3390/cryst10060472. 


\section{Results and discussion}

\section{Phase transition in $\left[\mathrm{Mn}(\mathrm{en})_{3}\right]\left(\mathrm{NO}_{3}\right)_{2}$ at $150(2) \mathrm{K}$}
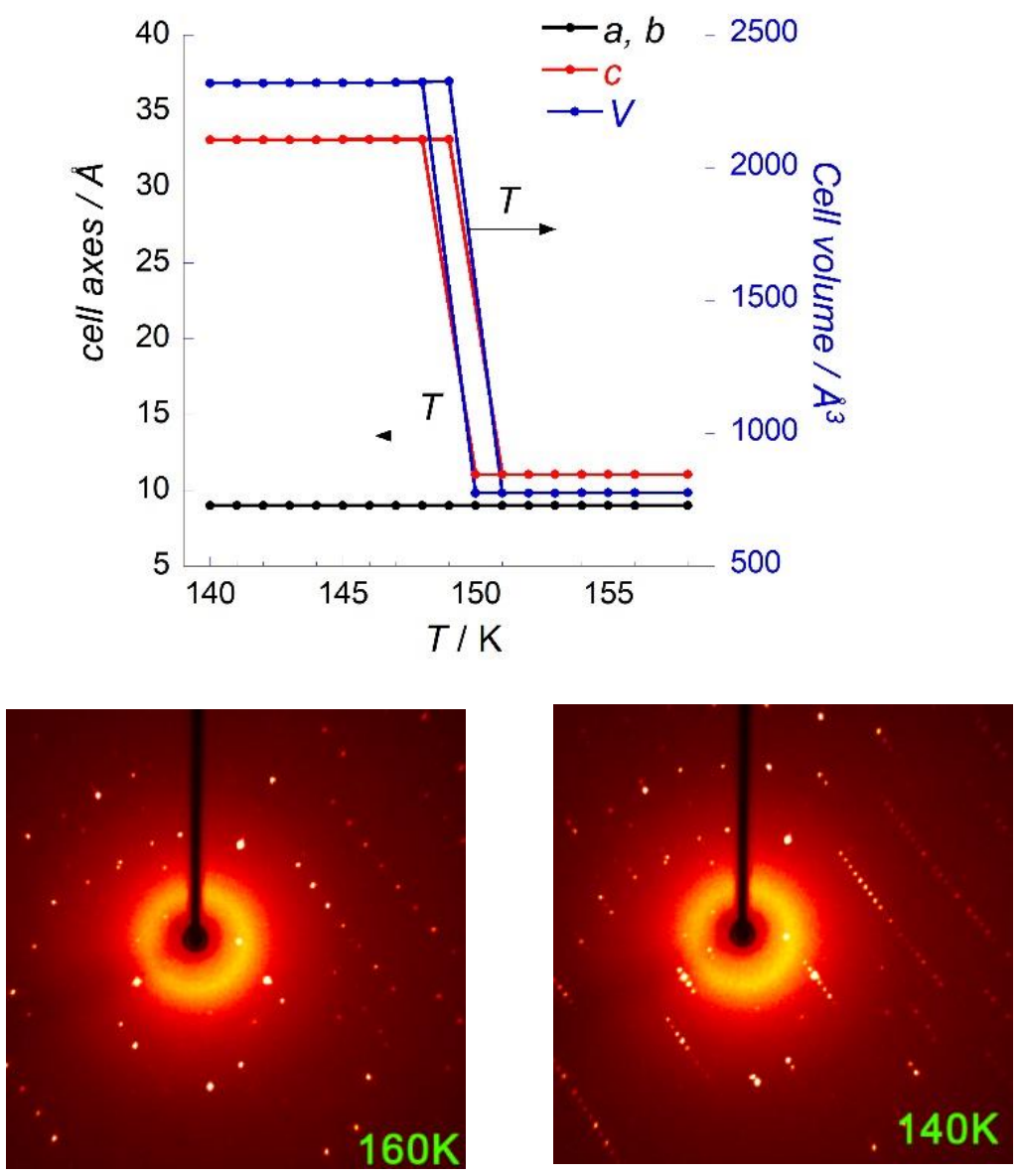

(top) Cell axes and volume as a function of temperature measured by $\mathrm{X}$-ray diffraction between 158 and $140 \mathrm{~K}$ on a single crystal of $\left[\mathrm{Mn}(\mathrm{en})_{3}\right]\left(\mathrm{NO}_{3}\right)_{2} ;$ (bottom) Diffraction images of $[\Lambda$ $\left.\mathrm{Mn}(\mathrm{en})_{3}\right]\left(\mathrm{NO}_{3}\right)_{2}$ at 160 and $140 \mathrm{~K}$ showing tripling of the Bragg peaks at LT.

M. Cortijo, A. Valentin-Perez, M. Rouzières, R. Clérac, P. Rosa, E.A. Hillard, Crystals, 2020, 10(6), 472 https://doi.org/10.3390/cryst10060472.

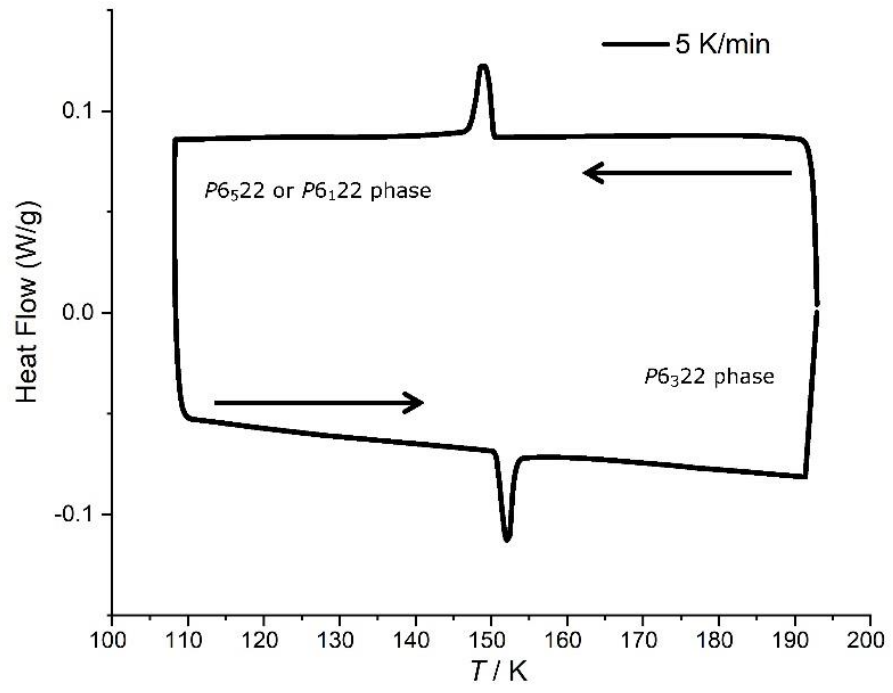

Differential scanning calorimetry trace for a powder sample of $\left[\mathrm{Mn}(\mathrm{en})_{3}\right]\left(\mathrm{NO}_{3}\right)_{2}$, scan rate 5 $\mathrm{K} / \mathrm{min}$. Top: cooling cycle; bottom: heating cycle. 


\section{Results and discussion}

\section{Absence of phase transition in $\left[\mathrm{Co}(\mathrm{en})_{3}\right]\left(\mathrm{NO}_{3}\right)_{2}$}
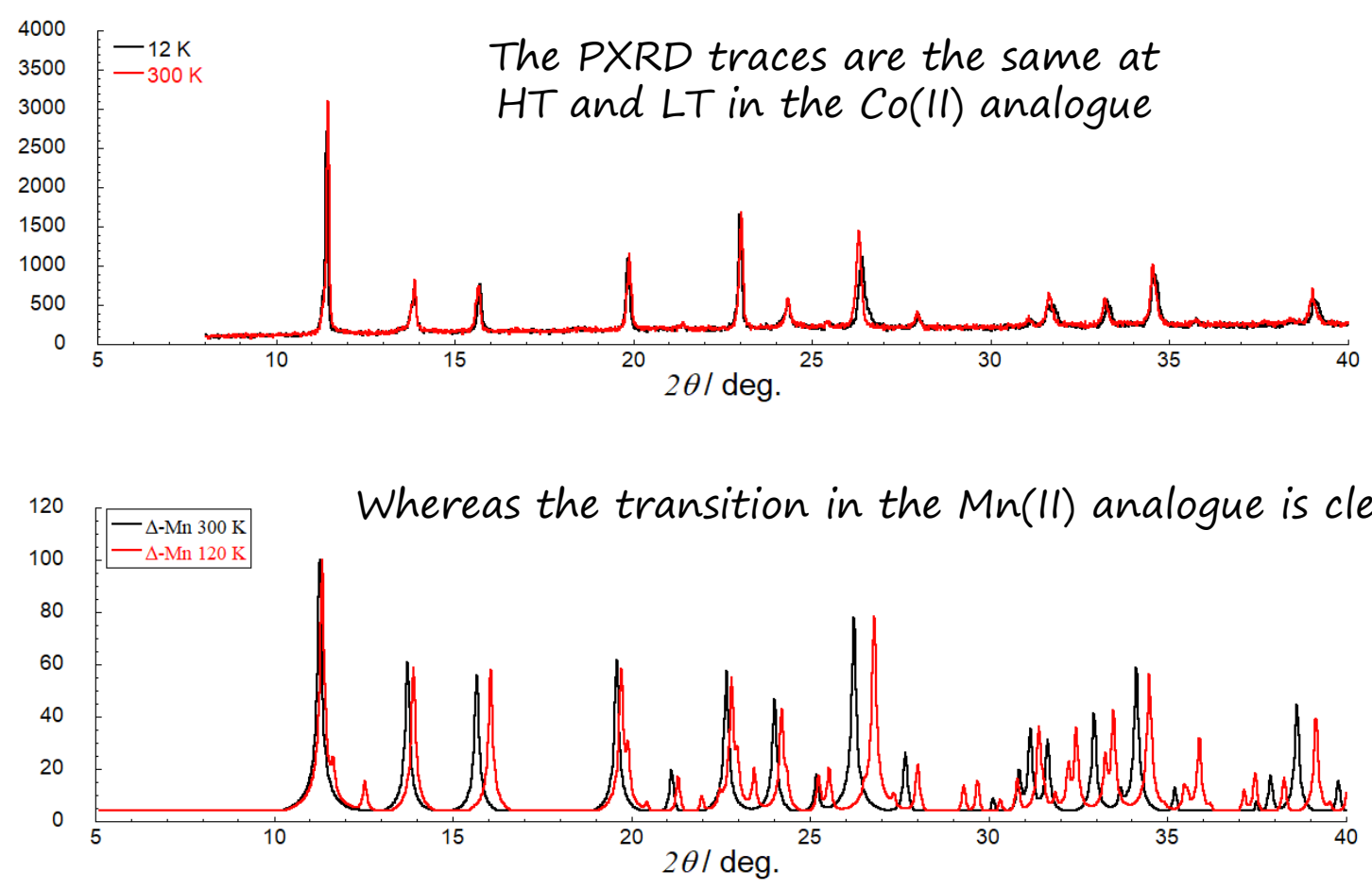

(top) Powder X-ray diffractograms for $\left[\mathrm{Co}(\mathrm{en})_{3}\right]\left(\mathrm{NO}_{3}\right)_{2}$ at 12 and $300 \mathrm{~K}$ showing no change with temperature; (bottom) Powder diffractograms simulated from $\Delta$ $\left[\mathrm{Mn}(\mathrm{en})_{3}\right]\left(\mathrm{NO}_{3}\right)_{2}$ single crystal data at 120 and $300 \mathrm{~K}$, which demonstrate the expected change upon the phase transition.
The featureless curve is taken as evidence for the lack of phase transition down to $2 \mathrm{~K}$.

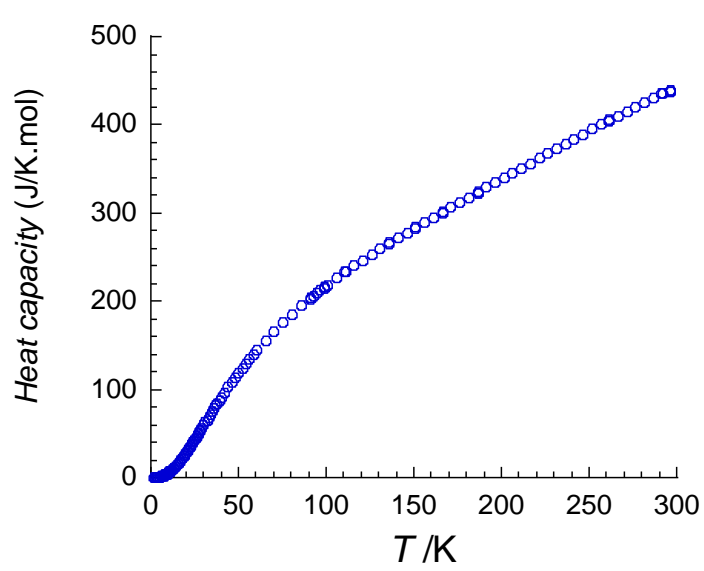

Heat capacity trace for a polycrystalline sample of $\left[\mathrm{Co}(\mathrm{en})_{3}\right]\left(\mathrm{NO}_{3}\right)_{2}$. 


\section{Results and discussion}

X-ray natural circular dichroism (XNCD)

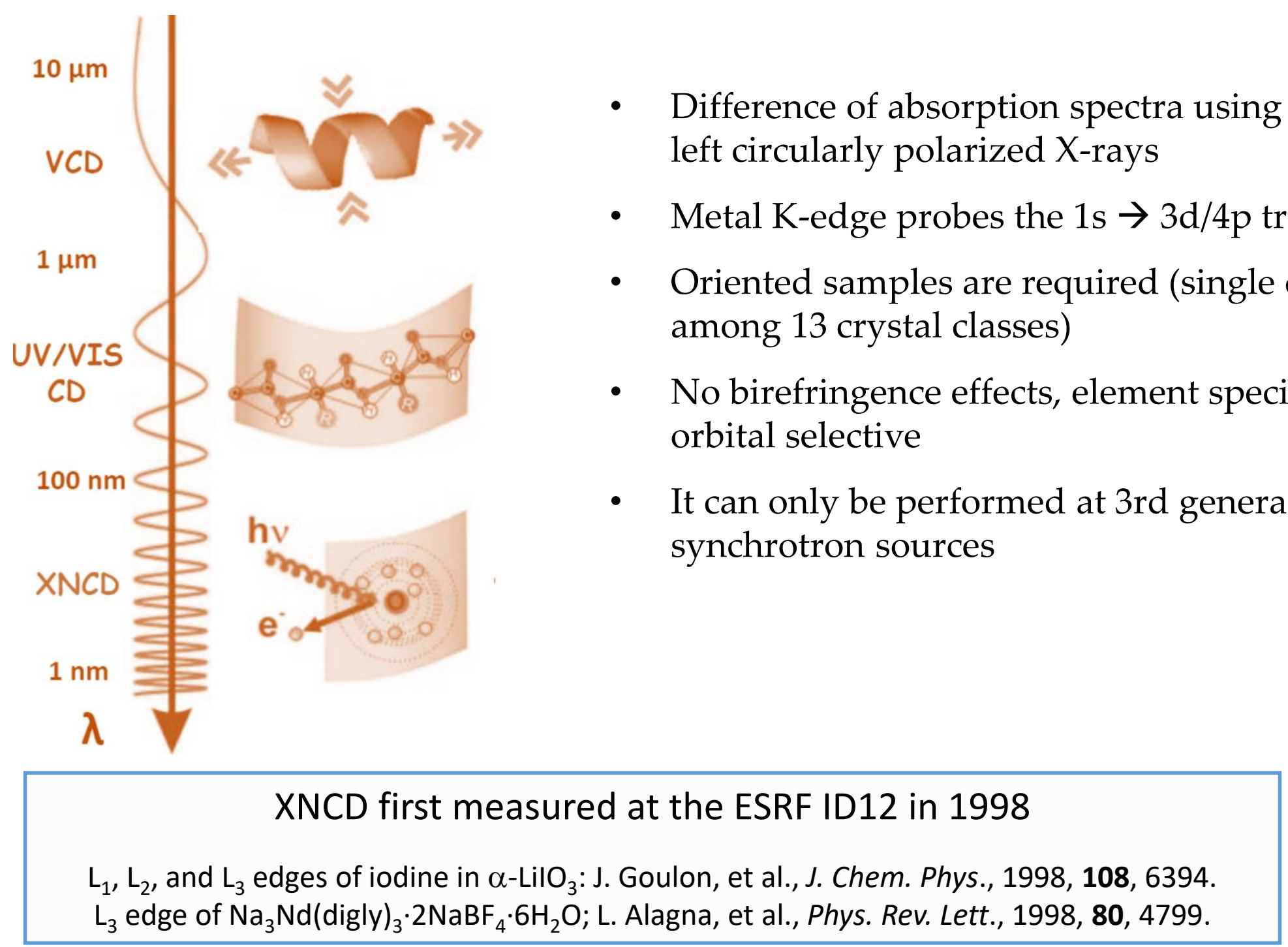




\section{Results and discussion}

$\mathrm{XNCD}$ of $\left[\mathrm{Co}(\mathrm{en})_{3}\right]\left(\mathrm{NO}_{3}\right)_{2}$ and $\left[\mathrm{Ni}(\mathrm{en})_{3}\right]\left(\mathrm{NO}_{3}\right)_{2}$

Performed on single crystals at room temperature at the ID12 of the ESRF

Mirror-image $C D$ in the $X$-ray range, with intense pre-edge features

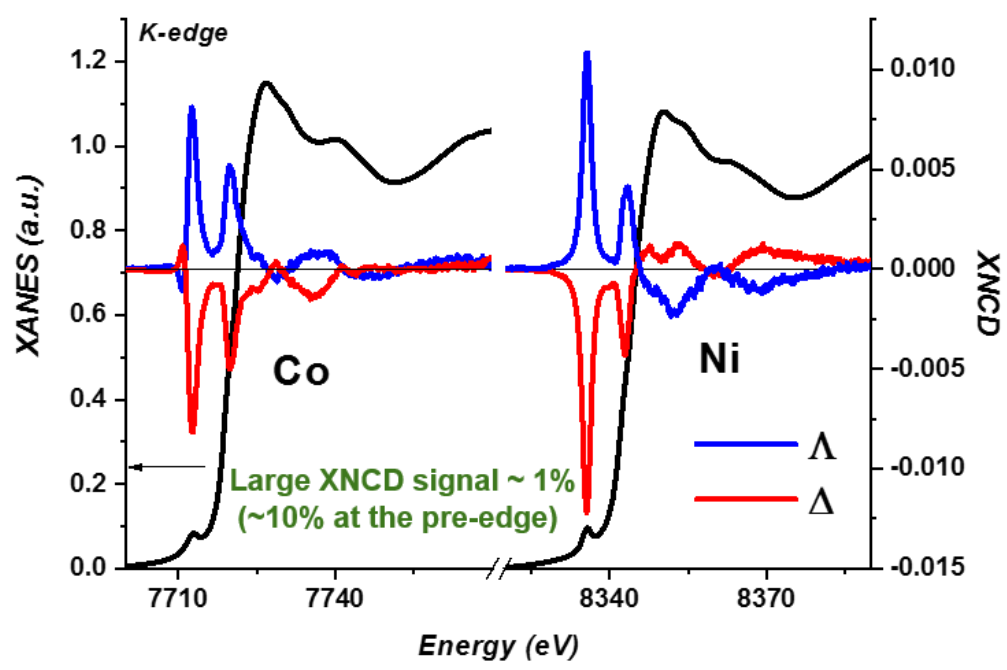

XNCD (blue and red lines) and X-ray absorption near edge spectra (XANES, black lines) spectra for $\left[\mathrm{Co}(\mathrm{en})_{3}\right]\left(\mathrm{NO}_{3}\right)_{2}$ and $\left[\mathrm{Ni}(\mathrm{en})_{3}\right]\left(\mathrm{NO}_{3}\right)_{2}$.
- Selecting crystals for this experiment was difficult, as the chirality of each crystal had to be determined by a full crystallographic data collection.

- $\quad$ Furthermore, we noticed that it was challanging to select a crystals of the $\Delta$ enantiomorph of the cobalt compound, suggesting unexpected enantiomeric enrichment (ee).

- How can we test this hypothesis by determining the crystalline ee in a conglomerate mixture? 


\section{Results and discussion}

Methods for determining individual crystal chirality in a conglomerate assembly

\section{Visual inspection requires hemihedry}
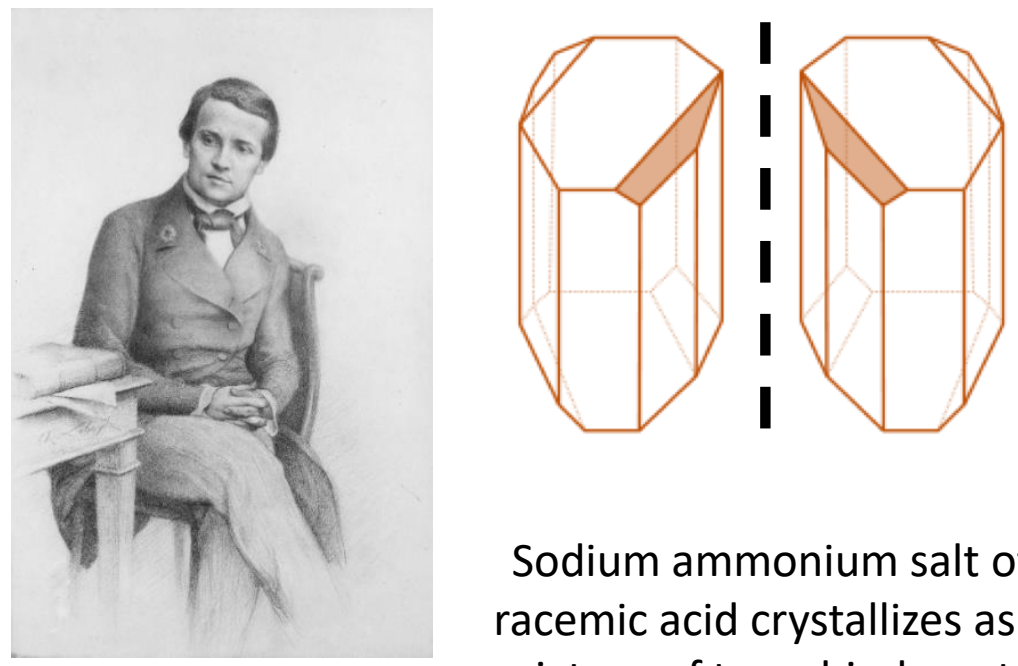

Sodium ammonium salt of racemic acid crystallizes as a mixture of two chiral crystal forms related by a mirror image
2. Polarized optical microscopy requires cubic, transparent crystals

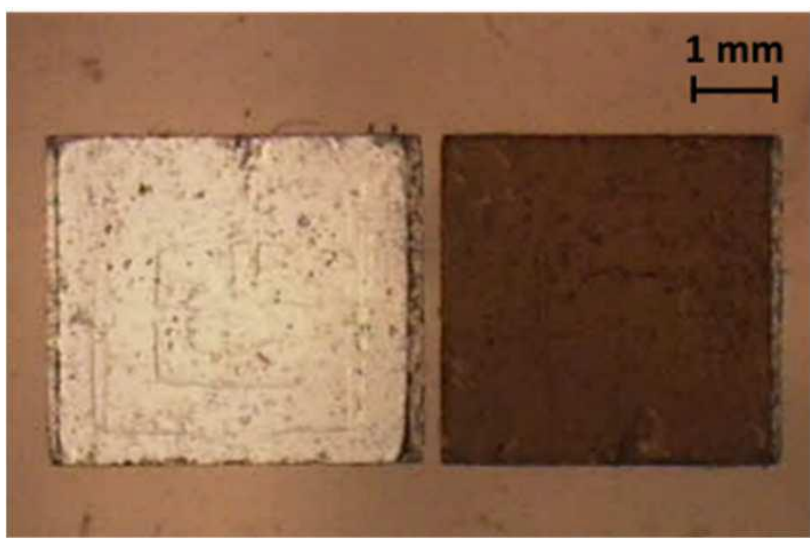

Enantiomorphic sodium chlorite crystals under POM (photo from the thesis of Manon Schlindler, University of Rouen, 2019).

3. X-ray crystallography time and labor intensive, impratical for the determination of the handedness of a statistically relevant number of crystals

Crystals 2020 


\section{Results and Discussion}

XNCD mapping

The X-ray energy was set to the energy corresponding to the maximum XNCD signal and passed over the sample plate while switching polarization, thus giving a negative or positive differential response
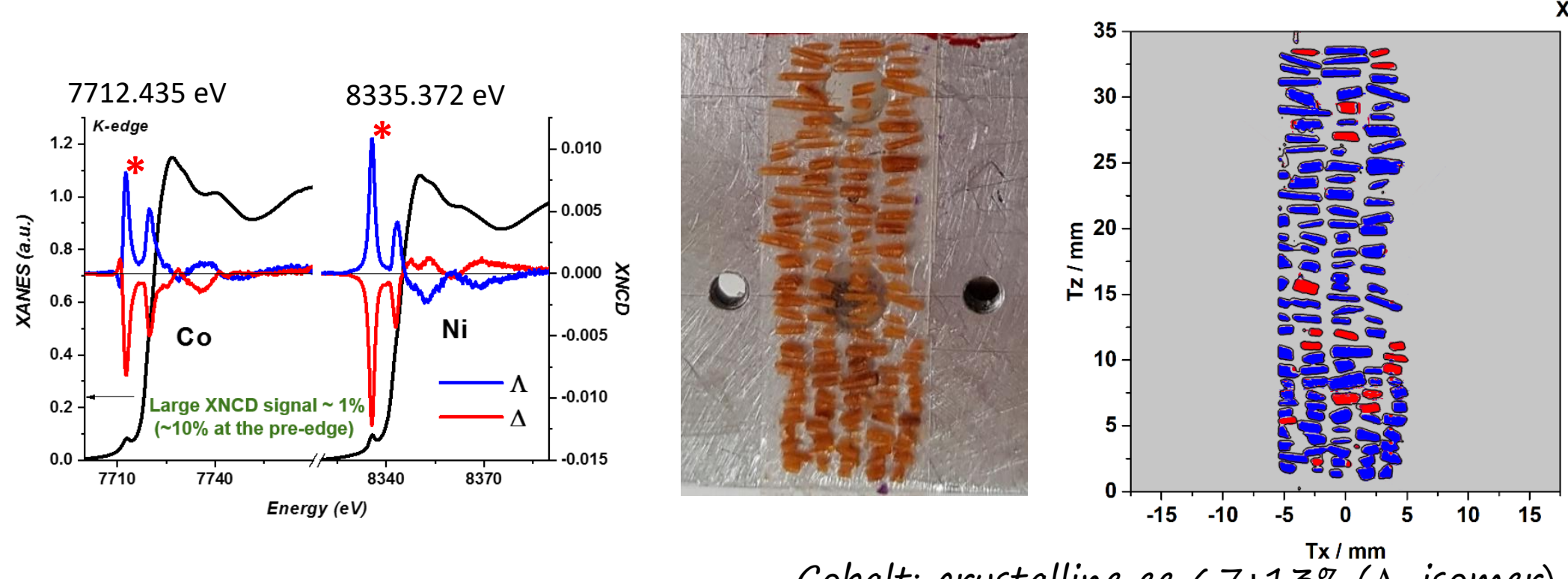

XNCD (7712.43 keV)

Cobalt: crystalline ee $67 \pm 13^{\mathrm{T} / \mathrm{mm}}(\Lambda$-isomer $)$

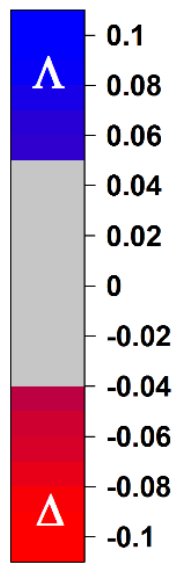

The unexpected enantiomeric excess was thought to be due to the influence of ascorbic acid, a chiral natural product, which was added to the reaction as an anti-oxidant. 


\section{Results and Discussion}

XNCD mapping

To confirm the effect of ascorbic acid, we mapped the nickel derivative in the presence and absence of the additive.
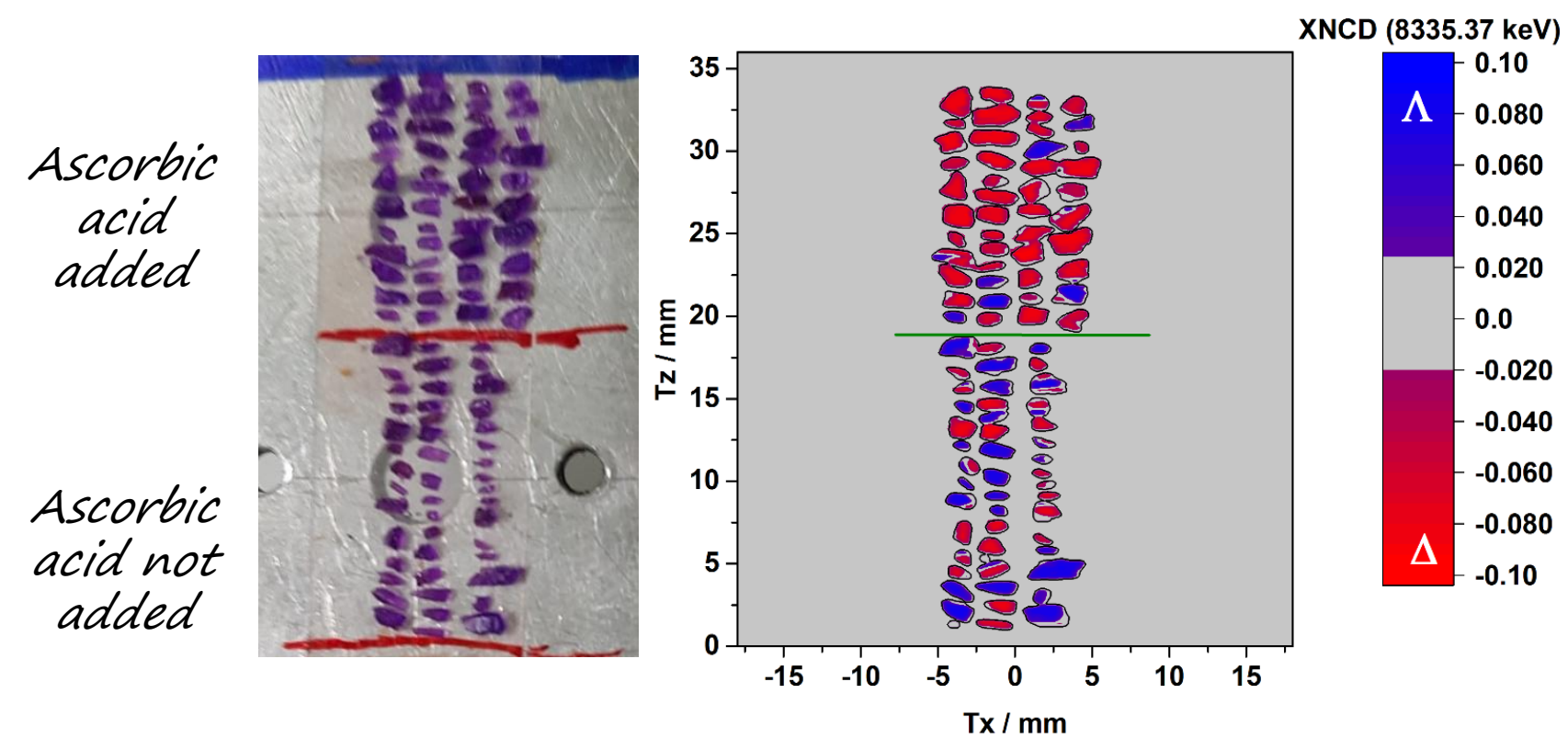

The presence of ascorbic acid results in enantiomeric excess for both compounds:

Cobalt: ee $67 \pm 13 \%$ $(\Lambda$-isomer $)$

Nickel: ee $65 \pm 22 \%$ $(\Delta$-isomer)

Nickel: no ee in the absence of ascorbic acid

Ascorbic acid drives enantiomeric enrichment, but in opposite directions for the $\mathrm{Co}(\mathrm{II})$ vs. the $\mathrm{Ni}(\mathrm{II})$ compound. 


\section{Conclusions}

- $\left[\mathrm{Mn}(\mathrm{en})_{3}\right]\left(\mathrm{NO}_{3}\right)_{2}$ and $\left[\mathrm{Co}(\mathrm{en})_{3}\right]\left(\mathrm{NO}_{3}\right)_{2}$ have been crystallographically characterized for the first time, and were found to be isostructural to the known $\mathrm{Zn}$ (II) and $\mathrm{Ni}(\mathrm{II})$ analogues, crystallizing as conglomerate mixtures.

- The Mn(II) analogue shows a phase transition at 150 (2) K, while no such transition is observed for the Co(II) derivative.

- The $\mathrm{Ni}(\mathrm{II})$ and $\mathrm{Co}(\mathrm{II})$ enantiomers show mirror-image X-ray natural circular dichroism signals with intense pre-edge features.

- The energy of the pre-edge XNCD peaks was used to map the crystal handedness of an assembly of crystals.

- Ascorbic acid has a differential effect on the complexes, resulting in an enrichment of the $\Lambda$ isomer for the Co(II) analogue and the $\Delta$ isomer for the $\mathrm{Ni}(\mathrm{II})$ analogue. 


\section{Acknowledgments}

Stéphanie Exiga - Rodolphe Clérac - Matthieu Rouzières
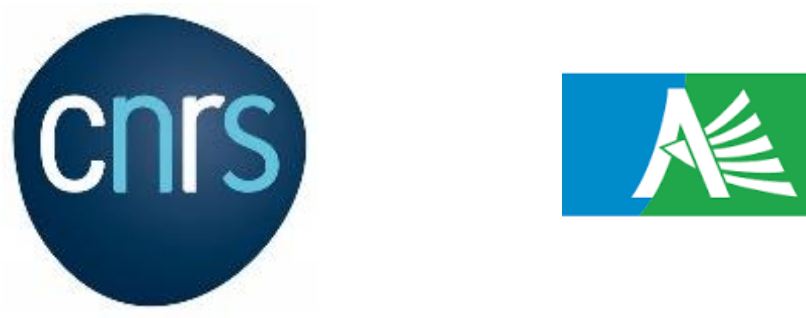

RÉGION AQUITAINE

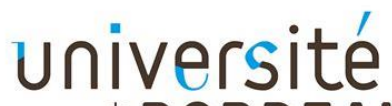
${ }^{d e}$ BORDEAUX

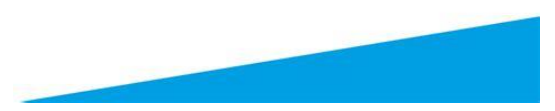

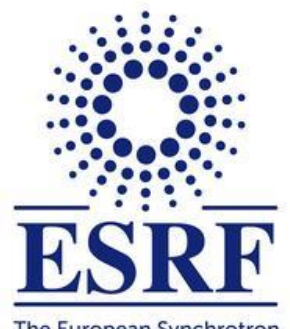

The European Synchrotron

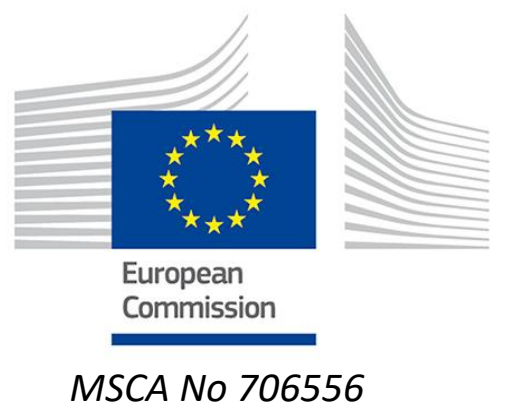

בע

MINISTÈRE DE L'ENSEIGNEMENT SUPÉRIEUR, DE LA RECHERCHE ET DE L'INNOVATION Liberté

Égalité

Fraternité

The authors declare no conflict of interest. 